\title{
POWER SITE VALUE IN EMINENT DOMAIN PROCEEDINGS: A NEW TOLL CHARGE FOR WATER RESOURCE DEVELOPMENT*
}

The conventional measure of "just compensation" 1 in eminent domain proceedings is the fair market value of the property at the time of the taking.2 This value reflects the most profitable uses available to the ordinary holder of the property ${ }^{3}$ uses available only to the taker may not be considered. ${ }^{*}$ The uses to which property under and along navigable streams may be put by the ordinary holder are limited by a servitude in favor of navigation granted to the Federal Government by the commerce clause of the Constitution." Thus,

*United States v. Twin City Power Co., 215 F.2d 592 (4th Cir. 1954), cert. granted, 348 U.S. 910 (1955) ; United States v. Twin City Power Co., 221 F.2d 299 (5th Cir.), petition for cert. filed, 24 U.S.L. WEEK 3029 (U.S. July 6, 1955) (No. 209).

1. "[N]or shall private property be taken for public use, without just compensation." U.S. Const. amend. V. By construction the fourteenth amendment imposes a similar obligation on the states. Chicago, B. \& Q.R.R. v. Chicago, 166 U.S. 226 (1897).

2. United States v. Commodities Trading Corp., 339 U.S. 121 (1950); United States v. Felin \& Co., 334 U.S. 624 (1948) ; Housing Authority v. Title Guarantee Loan Co., 243 Ala. 157, 8 So. 2d 835 (1942) ; In re Jeffries Homes Housing Project, 306 Mich. 638, 11. N.W.2d 272 (1943); Orgei, Valuation Under Earinent Domatn $\$ 17$ (2d ed. 1953).

3. United States ex rel. TVA v. Powelson, 319 U.S. 266 (1943); Olson v. United States, 292 U.S. 246 (1934); Decatur Park Dist. v. Becker, 368 I1l. 442, 14 N.E.2d 490 (1938).

4. United States v. Miller, 317 U.S. 369 (1943) ; Union Co. v. Moffat Dist., 104 Colo. 109, 89 P.2d 257 (1939); Grand Hydro v. Grand River Dam Authority, 192 Okla. 693, 694, 139 P.2d 798, 800-01 (1943) (dictum); Hale, Valne to the Taker in Condemnation Cases, 31. Colurs. L. Rev. 1 (1931).

5. Several decisions refer to the federal interest as a navigational servitude. E.g., United States v. Kansas City Life Ins. Co., 339 U.S. 799 (1950) ; Gibson v. United States, 166 U.S. 269 (1897). Others speak of it as a public right of navigation. E.g., United States v. Chandler-Dunbar Co., 229 U.S. 53 (1913). Others describe the interest as a power to improve navigation. E.g., United States v. Chicago, M. St. P. \& P.R.R., 312 U.S. 592 (1941). And still others denominate it both a servitude and a power. E.g., United States v. Commodore Park, Inc., 324 U.S. 386 (1945).

Analysis of the government interest in terms of a servitude or right is technically incorrect, since the commerce clause delegates to the Government power, not property. United States v. Central Stockholders' Corp., 52 F.2d 322 (9th Cir. 1931); The Supreme Court, 1949 Term, 64 HARv. L. Rev. 114, 139. However, description as a power to improve navigation is inadequate. The exercise of all governmental powers is conditioned by the requirement of just compensation. Monongahela Navigation Co. v. United States, 148 U.S. 312 (1893). But the Government may take stream beds to improve navigation without compensation. United States v. Chandler-Dunbar Co., supra. The Government's interest is best described by what Hohfeld calls a privilege. HoHFend, Fundarental Legar Conceptions 39 (1923). However, the term servitude is used hereafter, since it is the most accurate term yet sanctioned by the courts.

The navigational privilege does not extend to the beds of streams not navigable in fact. Hence damage to interests in such streams caused by navigational improvements is com- 
a riparian may not dam a navigable stream without government consent. ${ }^{6}$ Accordingly, in United States v. Chandler-Dunbar Co., the Supreme Court held that the Government could remove a private dam, in order to improve navigation, without compensating its owner. And since the riparian had no right to maintain the dam, he was denied compensation for the value of his fast land-land above the high-water mark-attributable to its suitability for use as a power site. ${ }^{8}$

Lower courts have disagreed on the question whether power site value must be granted where land is taken for dams not intended primarily to improve navigation." For the Government's "navigational" servitude originated with cases decided at a time when navigation was the sole federal interest in streams. ${ }^{10}$ More recently the Supreme Court has made clear that the commerce power authorizes construction of projects for such purposes as flood control and generation of electricity, ${ }^{11}$ but it has never had occasion to decide whether the Government's servitude is as broad as its power over commerce. ${ }^{12}$

In two recent cases entitled United States $v$. Twin City Power Co., ${ }^{13}$ both

pensable. Compare United States v. Kansas Life Ins. Co., supra (compensation awarded for damage along non-navigable stream), with United States v. Chicago, M. St. P. \& P.R.R., supra (compensation denied for damage along navigable stream). And compare United States v. Cress, 243 U.S. 316 (1917) (compensation awarded for reduction of capacity of power plant along non-navigable river), with United States v. Willow River Power Co., 324 U.S. 499 (1945) (compensation denied for reduction of capacity of power plant at confluence of navigable and non-navigable streams).

6. Act of Sept. 19, 1890, c. 907, \$ 7, 26 STAT. 454; 30 STAT. 1151 (1899), 33 U.S.C. $\S 403$ (1952). Accord, Union Bridge Co. v. United States, 204 U.S. 364 (1907) (bridges prohibited); Atlee v. Packet Co., 88 U.S. (21 Wall.) 389 (1875) (piers prohibited); Lewis Blue Point Oyster Co. v. Briggs, 229 U.S. 82 (1913) (oyster cultivation destroyed).

7. 229 U.S. 53 (1913). Chandler-Dunbar had built its dam under a revocable permit. Id. at 71 .

8. Id. at 76. See also United States v. Willow River Co., 324 U.S. 499 (1945) (identical reasoning).

9. In Washington Water Power Co. v. United States, 135 F.2d 541 (9th Cir.), cert. deticd, 320 U.S. 747 (1943), power site value was excluded from an award for land taken for the Grand Coulee Dam, the primary function of which is power production. See also United States v. West Virginia Power Co., 56 F. Supp. 298 (S.D. W.Va. 1944) (power site value excluded from an award for land taken for a flood control-power generation project) ; Continental Land Co. v. United States, 88 F.2d 104 (9th Cir.), cert. deried, 302 U.S. 715 (1937) (dictum). But see United States v. Twin City Power Co., 215 F.2d 592 (4th Cir. 1954), cert. granted, 348 U.S. 910 (1955) (power site value granted); United States v. Twin City Power Co., 221 F.2d 299 (5th Cir.), petition for cert. filed, 24 U.S.L. WeEK 3029 (U.S. July 6, 1955) (No. 209) (same).

10. See cases cited notes 5-7 supra. The Government did not undertake a large-scale multiple-purpose development until 1928. 1 RePort of THE PRESIDENr's Water Resources Policy Comiarission 255 (1950).

11. E.g., Oklahoma v. Atkinson Co., 313 U.S. 508 (1941) ; United States v. Appalachian Power Co., 311 U.S. 377, 426 (1940).

12. See United States v. Gerlach Live Stock Co., 339 U.S. 725, 737 (1950).

13. 215 F.2d 592 (4th Cir. 1954), cert. granted, 348 U.S. 910 (1955); 221 F.2d 299 (5th Cir.), petition for cert. filed, 24 U.S.L. WeEK 3029 (U.S. July 6, 1955) (No. 209). 
involving land condemned for the same power project, the Fourth and Fifth Circuits gave the condemnee power site value. Between 1901 and 1911, Twin City had acquired land on the Georgia and South Carolina sides of the navigable Savannah River as the site for a hydroelectric project. ${ }^{14}$ But in 1947 the land was still vacant, and the Government condemned it to build a lockless dam designed for flood control and generation of electricity. ${ }^{15}$ A special commission found that as farm land the property was worth $\$ 241,389,{ }^{16}$ as a dam site $\$ 1,257,033 .{ }^{17}$ United States district courts in South Carolina and Georgia awarded the larger sum, the Fourth and Fifth Circuits affirmed, and the Supreme Court has granted certiorari. ${ }^{18}$

14. Transcript of Record, p. 62, United States v. Twin City Power Co., 221 F.2d 299 (5th Cir. 1955) (hereinafter cited as Transcript). Six federal statutes enacted between 1901 and 1919 gave the power company permission to construct a dam. But Twin City failed to act and the permits expired. Brief for Appellees, p. 5, United States v. Twin City Power Co., supra.

15. United States v. Twin City Power Co., 215 F.2d 592 (4th Cir. 1954). The Government argued that the declaration in Act of Dec. 22, 1944, c. 665, $\$ 10,58$ ST 1 T. 891 , that the project was for the improvement of navigation, was controlling on the courts. Brief for Appellant, pp. 15-16, United States v. Twin City Power Co., 221 F.2d 299 (5th Cir. 1955). The Supreme Court has not decided whether a congressional recital of a navigational purpose is conclusive in compensation proceedings. United States v. Gerlach Live Stock Co., 339 U.S. 725, 737 (1950). The Court, however, has generally considered such declarations binding in deciding whether projects are for a constitutional purpose. E.g., Oklahoma v. Atkinson Co., 313 U.S. 508 (1941) ; Arizona v. California, 283 U.S. 423, 45657 (1931). But where the question is whether the Government is privileged to take without compensation, lower courts have not considered such statements conclusive. E.g., United States v. Gerlach Live Stock Co., 76 F. Supp. 87 (Ct. Cl. 1948), aff'd on other graunds, 339 U.S. 725 (1950) ; United States v. Central Stockholders' Corp., 43 F.2d 977 (S.D. Cal. 1930), aff'd on other grounds, 52 F.2d 322 (9th Cir. 1931). The fact that the Twin City dam is lockless does not necessarily preclude a purpose to aid navigation, as Congress may block navigation at one place to improve it at another. United States v. Commodore Park, Inc., 324 U.S. 386 (1945).

16. Brief for Appellant, p. 6, United States v. Twin City Power Co., 221 F.2d 299 (5th Cir. 1955). There is a discrepancy between the figure reported in Appellant's Brief and the figure of $\$ 150,831$ given in the commission's report, Transcript, pp. 96-99, apparently attributable to a clerical omission of the value assigned to one tract of land.

The valuation proceedings in South Carolina and Georgia were consolidated and referred to commissioners appointed pursuant to FED. R. CIV. P. 71A (h). Transcript, p. 22.

17. Transcript, p. 88. The commission's appraisal was based mainly upon a production cost comparison of hydroelectricity with its most efficient substitute, steam generated electricity. Id. at 85 . There was evidence that the site was economically suited for satisfying an increasing regional power demand, id. at 166-69, and that Twin City would have built a dam capable of producing $200,000,000$ kilowatt hours of electricity annually, $i d$. at 86,177 . Therefore the commission accepted an expert's conclusion that a buyer would pay for Twin City's land a sum equal to about one-half of the capitalized cost differential between producing $200,000,000$ kilowatt hours of electricity annually by water and by steam. The capitalized cost differential was divided in half to account for the cost of acquiring additional land and the market risk. Id. at 87.

18. United States v. 3,928.09 Acres of Land, 114 F. Supp. 719 (W.D.S.C. 1953), aff'd sub nom., United States v. Twin City Power Co., 215 F.2d 592 (4th Cir. 1954), ccrt. 
The Fourth Circuit's explanation for its decision disregarded both ChandlerDunbar and the basic principle that just compensation need reflect only uses available to the ordinary holder of the property. The court held simply that when fast land is taken, for whatever purpose, the Government's servitude in the stream bed is irrelevant in determining just compensation. ${ }^{10}$ Since the court recognized that only the Government or its licensee had a right to dam the stream, and that Twin City had no such right, ${ }^{20}$ it necessarily used value to the taker, rather than value to the ordinary user, as the measure of compensation. The most relevant authority given for the decision was a ruling in Chandler-Dunbar awarding canal and lock site value to a riparian property owner. ${ }^{21}$ But this ruling appears to have been based on the theory that the riparian had a right to build such structures, since they were aids rather than obstructions to navigation. ${ }^{2}$ And in the principal holding of that case, the Supreme Court reduced the award for fast land by the amount attributable to its usefulness as a dam location, reasoning that if no right to build a dam exists, power site value cannot be given. ${ }^{23}$

The Fifth Circuit avoided using the prohibited "value to the taker" standard and distinguished Chandler-Dunbar by holding, in effect, that at the time of the taking Twin City had a right to build a dam. The court reasoned that private rights in the bed of a navigable stream are subject only to the right of the sovereign to maintain or improve navigation, not a right to generate electricity or control floods. ${ }^{24}$ Given this premise, the Government's construction of a dam which made navigation impossible may be considered an abandonment of the servitude which had previously restricted the land uses available to the riparian property owner. ${ }^{25}$ Power generation became a use "available" to the ordinary holder, and power site value was relevant in determining just compensation.

At a doctrinal level, the basic question in both Twin City cases was whether the company had a "right" to dam the Savannah River for power production purposes. 26 This question is unanswerable in terms of doctrine, however, since

grantcd, $34 S$ U.S. 910 (1955) ; United States v. 12,122.54 Acres of Land, Civil No. 432, S.D. Ga., Aug. 26, 1953, aff'd sub nom., United States v. Twin City Power Co., 221 F.2d 299 (5th Cir.), petition for cert. filed, 24 U.S.L. WeEK 3029 (U.S. July 6, 1955) (No. 209).

19. United States v. Twin City Power Co., 215 F.2d 592, 597 (4th Cir. 1954).

20. Ibid.

21. Id. at 599, citing United States v. Chandler-Dunbar Co., 229 U.S. 53, 76-77 (1913).

22. United States v. Chandler-Dunbar Co., supra note 21. See Boom Co. v. Patterson, 98 U.S. 403 (1878) (riparian right to structure not impeding navigation recognized in compensation award). But see Greenleaf Lumber Co. v. Garrison, 237 U.S. 251 (1915) (government decision on what obstructs navigation conclusive).

23. United States v. Chandler-Dunbar Co., 229 U.S. 53, 76 (1913).

24. United States v. Twin City Power Co., 221 F.2d 299, 300 (5th Cir. 1955).

25. The court did not employ the servitude and abandonment terminology used in the text above. However, the analogy is suggested by their reasoning. See id. at 300-01. The servitude phraseology is used in the text for reasons given in note 5 supra.

26. If Twin City had a "right" to dam the Savannah which was restricted in the 
the rationale of all property "rights" is tautological. Thus, an "interest" is a "right" only if it is protected by courts ${ }^{27}$ and only if it is a "right" will it be protected. Inevitably, courts must break this circle by referring to policy considerations. ${ }^{28}$ A primary policy of the law of property, particularly in the context of just compensation, is that the reasonable expectations of the public should be honored. ${ }^{29}$ Thus courts typically refer to history in order to determine whether prior decisions gave reasonable grounds for belief that the interest in question would be given protection by the law. ${ }^{30}$ The honoring of reasonable expectations is not the sole relevant policy, however. Particularly where historical inquiry is inconclusive, courts seek to determine whether the broader public interest would be served by sanctioning a new property right, as by encouraging development or use of latent resources. ${ }^{31}$

If history does not entirely exclude the possibility that legal protection would be extended to an inchoate right to dam, it is at best inconclusive. In dealing

interest of navigation, its situation would be similar to that of the landowner whose right to produce oil is restricted in the interest of conservation. Restriction of oil production is not a taking, and therefore the government need not compensate. Ohio Oil Co. v. Indiana, 177 U.S. 190 (1899). But if the state or its licensee condemned the land to produce oil, the owner would be entitled to the value of his land as an oil-producing property. Cf. Thompson v. Consolidated Gas Co., 300 U.S. 55 (1937).

27. "But not all economic interests are 'property rights'; only those economic advantages are 'rights' which have the law back of them, and only when they are so recognized may courts compel others to forbear from interfering with them or to compensate for their invasion. . . . We cannot start the process of decision by calling such a claim as we have here a 'property right' ; whether it is a property right is really the question to be answered." United States v. Willow River Co., 324 U.S. 499, 502-03 (1945). See also Haelan Laboratories, Inc. v. Topps Chewing Gum, Inc., 202 F.2d 866, 868 (2d Cir. 1953) (dictum); McDougal \& Haber, Property, Wealth, Land 28 (1948) ; Restatement, Property $§ 1$ (1946) ; Cohen, Transcendental Nonsense and the Functional Approach, 35 CoLva. L. KEv. 809, 815 (1935).

28. Cohen, supra note 27, passim. See also Cardozo, The Nature of the Judicial Process 112-24 (1921).

29. See, e.g., United States v. Kansas City Ins. Co., 339 U.S. 799 (1950), in which the Court refused to extend the navigational servitude to tributaries of navigable streams expressly because riparians of the latter, unlike riparians of navigable streams, had no notice that their property could be taken without compensation. See also Benthas, THE Theory of Legislation 111-13 (Ogden 1931) ; Cardozo, op. cit. supra note 28, at 150-51; Fuld, The Commission and the Courts, 40 CoRNeLt. L.Q. 646-47 (1955).

30. "In the law of the land, more than in any other branch of law, . . the method of history supplies the organon of interpretation for the work of legislators and judges. Deep into the soil go the roots of the words in which the rights of the owners of the soil find expression in the law. We do not readily uproot the growth of centuries." Techt v. Hughes, 229 N.Y. 222, 240, 128 N.E. 185, 190-91. (1920), per Cardozo, J. See also Mirehouse v. Rennell, I Cl. \& F. 527, 546, 6 Eng. Rep. 1015, 1023 (H.L. 1833) ; Carpozo, TнE Nature of the Judicial Process 51-66 (1921).

31. E.g., International News Serv. v. Associated Press, 248 U.S. 215 (1918) (property right in "news" protected) ; Hinman v. Pacific Air Transport, 84 F.2d 755 (9th Cir. 1936), cert. denied, 300 U.S. 654 (1937) (right to air space above land) ; Swetland v. Curtiss Airports Corp., 55 F.2d 201 (6th Cir. 1932) (same). See also Cardozo, The Nature of the Judicial Process 66-67 (1921). 
with the Government's privilege to take land free of dam site value, the Supreme Court has suggested by way of dictum both that the privilege is as broad as the needs of commerce, ${ }^{32}$ and that it is limited to takings in aid of navigation. $^{33}$ It is certain, however, that an actual right to dam navigable streams has never been successfully asserted. At common law a private dam in a navigable stream could be abated as a nuisance. ${ }^{34}$ Since 1890 , federal statutes have prohibited erection of private dams except by federal licensees, ${ }^{35}$ and the Supreme Court has held that the power to deny licenses is plenary. ${ }^{36}$ Investment in land for its value as a dam site would be highly speculative even if Twin City were affirmed, since the Government could still take it free of dam site value for use in connection with navigational improvements. ${ }^{37}$

Although courts will sometimes recognize new "rights" of property in order to encourage the development of resources, ${ }^{38}$ this policy seems plainly inapplicable to the "right" to dam recognized in Twin City. For this right does not entitle its owner to develop the resources of a stream $;^{39}$ it is a right only to additional compensation in condemnation proceedings. Indeed, the decision in Twin City can serve only to retard utilization of the nation's water resources. Certainly public power development will be hampered by the necessity of paying dam site value for land, a new and substantial cost item. ${ }^{40}$ But private

32. E.g., United States v. Appalachian Power Co., 311 U.S. 377, 427 (1940) ; United States v. Commodore Park, Inc., 324 U.S. 386 (1945). A lower court has held that riparians have no property rights in navigable streams enforceable against the Government. Washington Power $\mathrm{Co}_{0}$ v. United States, 135 F.2d 541 (9th Cir.), cert. denied, 320 U.S. 747 (1943). See United States v. Chandler-Dunbar Co., 229 U.S. 53, 69 (1913) (dictum).

33. E.g., United States v. River Rouge Co., 269 U.S. 411, 419 (1926) ; Port of Seattle v. Oregon \& W.R.R., 255 U.S. 56, 63 (1921).

34. Hale, De Jure Maris, in Moore, History of the Foreshore 374 (3d ed. 1888); Pennsylvania v. Wheeling \& Belmont Bridge Co., 54 U.S. (13 How.) 518, 565-67 (1851) (by implication). Even the king could not license an obstruction to navigation. Hale, First TrEatise, in Moore, op. cit. supra, at 338, 345. However, it is clear that the Government may permit obstruction of passage. Pennsylvania v. Wheeling \& Belmont Bridge Co., 59 U.S. (18 How.) 421 (1856).

The early English common law distinguished between navigable tidal streams, in which riparians had no rights whatever, and navigable fresh water streams, in which riparians had full title subject only to a public right of way. See Shively v. Bowlby, 152 U.S. 1, 11-13 (1S94) (dictum); HALE, DE JURE MARIs, in MOORE, op. cit. supra, at 370-74. This distinction was promptly discarded, however, as foreign to American topography. See, e.g., The Propeller Genesee Chief v. Fitzhugh, 53 U.S. (12 How.) 443 (1852).

35. See note 6 supra and accompanying text.

36. United States v. Appalachian Power Co., 311 U.S. 377, 427 (1940).

37. United States v. Willow River Co., 324 U.S. 499 (1945) ; United States v. Chandler-Dunbar Co., 229 U.S. 53 (1913). See United States v. Twin City Power Co., 221 F.2d 299, 300 (5th Cir. 1955) (dictum). But see United States v. Twin City Power Co., 215 F.2d 592, 599 (4th Cir. 1954).

38. See note 31 supra and accompanying text.

39. Congress has plenary power to deny licenses to dam navigable rivers. See notes 35-36 supra and accompanying text.

40. In deciding whether it should undertake a project, the Government weighs over-all cost against potential benefit. 1 Report of the President's Water Resources Policy 
development will be impeded as well. Private companies that are licensed to dam have the power of eminent domain, and will be required in condemnation proceedings to pay this exaction also. ${ }^{41}$ Development even by companies which have already acquired sites at low cost may be discouraged. If the company holds the land until it is taken by the Government or its licensee, windfall profits will be realized. ${ }^{42}$ But if the site is developed, this potential profit may never materialize, since utility company rates are regulated, and must reflect the original cost of production facilities when it is less than market value. ${ }^{43}$

To the extent that Twin City can be said to promote any aspect of resource development, it favors navigation over other needs of commerce. For dam site value must be paid only when property is taken for purposes other than navigation.4 But efficient development of water resources requires use of multiple purpose projects, emphasizing flood control, irrigation or hydroelectric power production, where appropriate, as well as navigation. ${ }^{45}$ Rarely will topography and need-factors which should dominate resource planning policy-dictate construction of projects intended primarily to improve water transportation. ${ }^{* 0}$ Therefore, unless the Government is willing to place an irrational emphasis on navigation in project planning, its servitude will have little value to the public. The Supreme Court has already noted that transportation on inland waterways

Connmission 59-65 (1950). The necessity of paying power value for land may result in disapproval of a government project. See Frank, The United States Suprome Court: 1948-49, 17 U. CHI. L. REv. 1, 17-18 (1949).

41. All federal licensees are vested with the power of eminent domain. 41 STAT. 1074 (1920), 16 U.S.C. $\$ 814$ (1952). The statute requires licensees to seek to acquire sites by contract prior to condemning, but they need not meet landowners' hold-up prices. See Wilson v. Union Elec. Light \& Power Co., 59 F.2d 580 (8th Cir. 1932). If the Government may not constitutionally take property without paying dam site value, it may not license others to do so. For discussion of whether licensees would be required to pay dam site value in condemnation proceedings if the Twin City decisions are reversed, see note 50 infra and accompanying text.

42. There are several ways by which power companies might have acquired dam sites without paying power value. Many sites were acquired at the turn of the century before the value of electricity was fully understood. See 3 Report of the President's Water Resources Policy CoMnmission 264 (1950). Moreover, state licensees have occasionally been allowed to obtain small tracts in condemnation proceedings without compensating for power value. See Olson v. United States, 292 U.S. 246 (1934); Note, 27 N.C.L. Rev. 359,364 (1949). And since no assurance could be had that a license to produce power would be granted, see text at note 36 supra, power site value would probably not have been paid for any site acquired by an unlicensed power company.

43. 41 StaT. 1073 (1920), 16 U.S.C. \& 813 (1952). Furthermore, the Government may recapture a project at the expiration of a license upon payment of cost or fair market value, whichever is lower. 41 STAr. 1071 (1920), as amended, 16 U.S.C. $\S 807$ (1952), United States v. Appalachian Power Co., 311 U.S. 377 (1940).

44. See cases cited note 37 supra.

45. 1 Report of the President's Water Resources Policy Conraission passim (1950), especially at 5-10, 43-54.

46. See $i d$. at 5. Navigation ranked as fourth and eighth in importance in two estimates of the amount of expenditures necessary per function for an adequate water resource development program. Id. at 93 . 
is no more important to commerce than other needs that may prompt federal expenditures for water resource development. ${ }^{47}$ No reason appears why the privilege to take land free of dam site value should not keep pace with the power to dam, so long as established property rights are not impaired.

The Fourth Circuit appeared to believe that private power companies licensed to dam would be required to pay dam site value for property they acquired. ${ }^{48}$ Given this premise, it might be argued that allowing the Government to acquire sites at lower cost would give it an artificial advantage over private power companies, thus prejudicing the public versus private power question. However, the assumption that private power companies licensed to dam would be required to pay dam site value in condemnation proceedings seems unwarranted. No court has ever had occasion to decide this question. ${ }^{49}$ When it arises, courts should employ the same standard that obtains for the Government itself, for the public must ultimately bear the cost of dam construction whether the Government or a private company pays it initially. ${ }^{50}$ In any event, the merits of the public versus private power controversy are now so distorted by differences in the impact of economic forces upon the Government and private companies, ${ }^{51}$ that creation of one additional element of inequality would

47. See Oklahoma v. Atkinson Co., 313 U.S. 508, 521-34 (1941); United States v. Appalachian Power Co., 311 U.S. 377, 426 (1940).

48. United States v. Twin City Power Co., 215 F.2d 592, 601 (4th Cir. 1955). All federal licensees are vested with the power of eminent domain. See note 41 supra.

49. See Grand River Dam Authority v. Grand Hydro, 335 U.S. 359, 373 (1948). In this case the Supreme Court affirmed a state decision requiring a taker, not acting as a federal licensee, to pay power value for land condemned along a non-navigable river. The Court expressly left open the question whether the Government or a federal licensee relying upon his federal power would have had to compensate for such value. Ibid.

50. The Fourth Circuit's view may have been based on cases which hold that, unlike the Government, licensees must compensate riparians for rights in the water's flow destroyed by dams already in operation. See, e.g., FPC v. Niagara Mohawk Power Co., 347 U.S. 238 (1954) ; Ford \& Son, Inc. v. Little Falls Co., 280 U.S. 369 (1929). However, these decisions are irrelevant to the dam site value question, since they are based on inapplicable sections of the licensing Act which explicitly required the result reached. Thus, the Act makes licensees liable for damage resulting from construction and maintenance of dams, and specifies that rights acquired under state statutes relating to appropriation and distribution of water are to remain intact. 41 STAT. 1069, 1077 (1920), 16 U.S.C. $\S \S 803(c), 821$ (1952). And rights in stream flow are determined by state law. E.g., Kansas v. Colorado, 206 U.S. 46, 91-94 (1907). But since the right to dam a navigable stream can exist only under federal law, First Iowa Cooperative v. FPC, 328 U.S. 152 (1946); United States v. Rio Grande Co., 174 U.S. 690, 707 (1899), the licensing Act does not affect the question whether dam site value must be paid in eminent domain. No policy reason for applying different standards to the Government and licensees is apparent since the public must ultimately bear the cost of dam construction in either event. See note 43 supra and accompanying text; Gilmore v. Power Co., 127 Me. 522, 145 Atl. 137 (1929).

51. For a discussion of the distortion due to the Government's tax immunity, see Beebee, Are Public Power Programs in the Public Interest?, 55 PUb. UTIL. ForT. 409, 414 (1955); Sporn, Obscrvations on Private versus Public Power, 53 id. 717, 730 (1954). On the Government's superior borrowing ability, see The Twentietr Century Fund, The 
seem an indifferent reason for burdening the public with this new charge on resource development.

It is difficult to perceive any sound policy purpose which is served by the Twin City decisions. The sole benefit from the rule they create will go to investors who either did not themselves pay dam site value, or speculated on the possibility that the Government or its licensee might condemn the land for some purpose other than the improvement of navigation. Both resource development policy and principles of just compensation should lead the Supreme Court to reverse Tzein City, and thus forestall a partial return to outmoded limitations on the Government's power over commerce.

Power Industry and the Public Interest 209 (1949); Woodbury, Niagara Should be a Business Company Project, 51 PUB. UTIL. ForT. 687, 692-93 (1953). Furthermore, licensees may be liable for damage where the Government would not be. See note 50 supra. 